\title{
EXPERIMENTAL RESEARCH REGARDING THE APPLICATION OF ELECTRO-FLUSHING METHOD ON DIESEL CONTAMINATED SOILS
}

\author{
Constantin Streche ${ }^{1}$, Adrian Badea ${ }^{1}$, Irina A.Istrate ${ }^{1}$, Diana \\ M.Cocârță ${ }^{1}$, Tiberiu Apostol ${ }^{1}$
}

Key words : decontamination, electroremediation, diesel fuel, soil, soil flushing

\begin{abstract}
In 2011, as a result of the inventory conducted at the national level, The Ministry Of Environment concluded that the largest number of contaminated sites with hydrocarbons are due to the petroleum products distribution (nearly 400 sites), followed by the hydrocarbons extraction (about 310 sites). So, soil contamination with liquid petroleum products resulting from many industrial activities became an important issue of environment protection. Unfortunately not all local governments have provided a list of contaminated sites, which means that there is a possibility to have a bigger problem at the national level. All these surfaces are in a continuous growth due to industrial and social development and that is why it is necessary to study and improve decontamination methods of contaminated sites in order to regain one of our most important resources - the soil. In this paper, the main results obtained during a research that aimed to study two different treatment methods of contaminated soil in a combined solution, are presented. The newly developed method is called electro-flushing. Results proved that combining the two nominated methods could be a viable solution for treating diesel polluted soil with better performances comparing with using them separately. Concerning the electrochemical treatment of diesel contaminated soils an efficiency of 35-40\% could be obtained after 28 days; while using the flushing method up to $15-20 \%$ efficiency could be reached. On the other hand, if we combine these two methods, we can reach remediation efficiency up to $50 \%$. So, the main interesting results of the present research is given by the fact that combining two known remediation methods, better performances could be achieved.
\end{abstract}

\footnotetext{
${ }^{1}$ University 'Politehnica' of Bucharest, Romania, constantin_xxl@yahoo.com
} 


\section{Introduction}

The issue of contaminated soils with liquid petroleum products is one of the most complex challenges in the field of environmental protection, from the theoretical and economic point of view and in terms of the implementation of remediation methods. In the case of a surface discharge with petroleum products such as, crude oil or fuel oil, the negative effects extend into short time from the initial contamination especially in the upper soil profile, due to a high viscosity of the products, and in the atmosphere by evaporation of slightly volatile compounds. In the case of gasoline or diesel, the pollution can affect both the soil, subsoil and could reach even to the groundwater aquifers. Diesel fuel is a product obtained by petroleum distillation and it is composed of $75 \%$ saturated hydrocarbons and 25\% polycyclic aromatic hydrocarbons (PAH).

Of the medium products obtained through oil distillation, products that are used in terrestrial situations, diesel oil has the highest content of PAHs (Wang et al., 1990) which makes it more difficult to remediate.

Polycyclic aromatic hydrocarbons, like any other aromatic compounds, represent a real danger for human health and vegetation, because of their powerful mutagenic and carcinogenic character.

Diesel pollution can cause changes in biochemical and chemical processes for plants and soil, causing ecological imbalances in chain, with bad consequences on the stability, vitality and regeneration capacity of terrestrial ecosystems. It was proven that at relatively low levels of diesel fuel contamination, delayed seed emergence and reduced percentage germination for the majority of plant species. In addition, the remaining diesel fuel in the soil added to this inhibitory effect on germination by physically impeding water and oxygen transfer between the seed and the surrounding soil environment, thus hindering the germination response (Gillian et al, 2002).

This paper is illustrating a combined a solution for the above problems: reducing the concentration of diesel in the soil by chemical and physical methods such as electro-flushing.

\section{Remediation treatment of soils}

Electrokinetic remediation methods may destroy, carry and concentrate a diverse range of organic pollutants that can be found in different types of soil, except in those with an increased hydraulic permeability (sandy). This method involves the use of electrodes placed in the ground in various configurations and the application of potential differences at their ends. The established current produces in soil various physical and chemical phenomena, underlying 
technologies for continuous current (DCT), like: electrolysis, electrophoresis, electro-osmotic flow, etc.

Electrolysis is the phenomenon that involves electrolyte decomposition in the presence of electric current through the migration of electrolyte ions to electrodes where a potential difference was applied. Electromigration represents ions transport under the electric field influence, the positive ions move towards the cathode and the negative ions move towards the anode. Electroosmosis is the process by which under the influence of electric current the water present in soil is moving from the anode to the cathode, creating this way an electroosmotic flow. Electrophoresis is the motion of the charged particles under the influence of electric field (Acar et al, 1995).

In the present work, for soil decontamination two different methods were combined: electro-remediation and "soil flushing". This is the reason for which the authors named the process as electro-flushing. Soil flushing is a method that involves pollutant concentration for the extraction or isolation using a natural pressure gradient or a created one, by injecting the flushing liquid with pumps. This technique has good results in soils with high permeability, but in clay soils (particles smaller than $0.02 \mathrm{~mm}$ ) cannot be applied. A major disadvantage of this process is that the liquid volume is disperses in all directions and cannot be directed entirely towards the extraction points (EPA, 1993).

Instead, through electro-flushing there is a guarantee to concentrate the entire volume of fluid that can be found in the treated soil mass towards the electrodes area through the above-mentioned transport processes. So, combining these two methods can lead to the possibility of an in-situ application with good results.

\section{Experimental tests}

The soil used during the experiment is identified as Luvisols with characteristics as shown in Tab. 1. Also the granulometry of the soil was determinate and the results are presented in Tab. 2. The experiment carried out consisted of the artificial contamination of $6 \mathrm{~kg}$ soil with an amount of $10 \%$ diesel. Initial soil moisture was 3.69\%. In order to stimulate the electrochemical processes, it was necessary to add an additional quantity of 1.21 of distilled water and so the final moisture reached $20.18 \%$. The obtained mix was introduced in an electrochemical cell where a current density of $1 \mathrm{~mA} / \mathrm{cm}^{2}$ was applied. The electrochemical cell has the next characteristics: 300x150x150 mm (Fig. 1).

The experimental setup used to apply the electro-flushing treatment was developed in the framework of a research project, co-financed by the Sectorial 
Operational Programme " Increasing Economic Competitiveness " POSCCEA2-O2.1.2.-2009-2, project called RECOLAND (ID519, SMIS-CSNR: 11982 (2010-2013)).

The stainless steel electrodes placed in the soil have the dimensions of $145 \times 130 \mathrm{~mm}$ and their body is a network of longitudinal slits $3 \mathrm{~mm}$. Also the body of the electrochemical cell provided a cross-section of $3 \mathrm{~mm}$ slits that will allow passing the effluent (water and diesel) that will be stored in two tanks located on each side of the installation. At a distance of $50 \mathrm{~mm}$ from the anode 3 cylindrical metal sieve tubes of diameter $10 \mathrm{~mm}$ at equal distances from each other were introduced. The three sites were introduced in 3 wells with a depth of $100 \mathrm{~mm}$ in soil. These shafts were fed regularly with distilled water $20 \mathrm{~g}$ on average 10 hours.

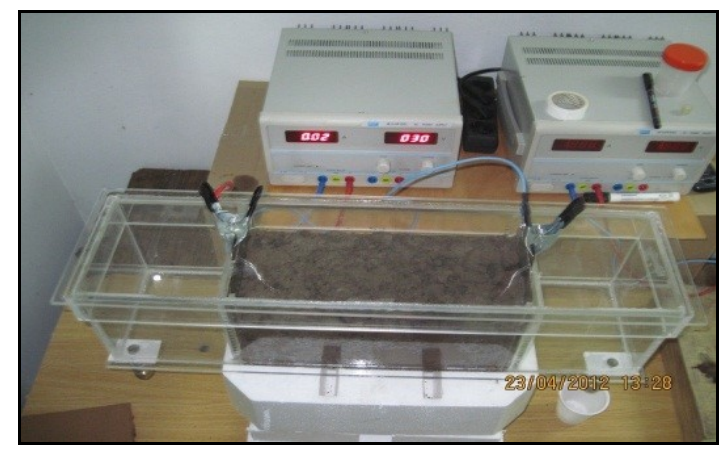

Fig. 1 - Experimental installation of electroflushing (top view)

Tab. 1. Properties of diesel contaminated soil used for the experimental tests

\begin{tabular}{|c|c|c|c|c|c|c|c|c|c|c|}
\hline \multirow{2}{*}{$\begin{array}{c}\text { Soil } \\
\text { characteristics }\end{array}$} & \multirow[t]{2}{*}{ PH } & \multirow[t]{2}{*}{$\mathrm{Nt}$} & \multirow[t]{2}{*}{ Humus } & \multirow{2}{*}{$\mathrm{P}_{\mathrm{AL}}$} & \multirow[t]{2}{*}{$\mathrm{K}_{\mathrm{AL}}$} & \multicolumn{4}{|c|}{$\begin{array}{l}\text { The mobile forms of } \\
\text { microelements }\end{array}$} & \begin{tabular}{|c|}
$\begin{array}{c}\text { The total soluble } \\
\text { salts content }\end{array}$ \\
\end{tabular} \\
\hline & & & & & & $\mathrm{Zn}$ & $\mathrm{Cu}$ & $\mathrm{Fe}$ & $\mathrm{Mn}$ & \multirow[b]{2}{*}{$\mathrm{mg} / 100 \mathrm{~g} \mathrm{sol}$} \\
\hline $\begin{array}{c}\text { units of } \\
\text { measurement }\end{array}$ & - & \multicolumn{2}{|c|}{$\%$} & \multicolumn{6}{|c|}{$\mathrm{mg} \mathrm{kg}^{-1}$} & \\
\hline identified values & 6,97 & 0,149 & 3,18 & 110 & 364 & 6,54 & 4,78 & 12,9 & 51,1 & 16 \\
\hline
\end{tabular}

Tab. 2. The grain size analysis

\begin{tabular}{|c|c|}
\hline Particle size & Percentage \\
\hline$[\mathbf{m m}]$ & {$[\%]$} \\
\hline 4 & 0,615 \\
\hline 2 & 6,365 \\
\hline 0,8 & 25,589 \\
\hline$<0,8$ & 67,431 \\
\hline
\end{tabular}




\section{Results}

The initial parameters of the experiment that was conducted were: the electric voltage $30 \mathrm{~V}$, while the intensity of electric current was $30 \mathrm{~mA}$. During the experiment, an attempt was made in order to maintain the same intensities of electric current. With this aim it was necessary to vary the electrical tension between $30 \mathrm{~V}$ to $90 \mathrm{~V}$.

The PH curve evolution (Fig. 1) shows a $\mathrm{pH}$ decrease in the anode area and an increase in the cathode are due to the water hydrolysis, which leads to the creation of an acid front at the anode moving towards the cathode, and a front base at cathode that moves towards the anode.

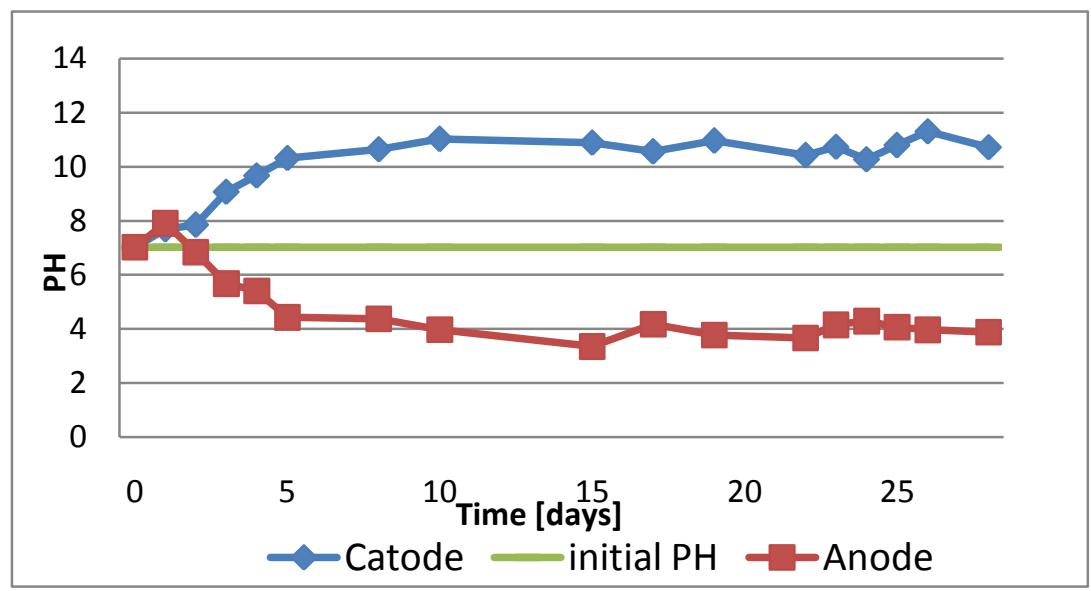

Fig. 2 - The trend of the PH variation during the treatment period

During the experiment, diesel in soil initial concentration was identified, but also after 15 and 30 days in order to identify changes of diesel concentration in time (Tab. 3.) All these analyses of the soil samples were made according to the Romanian analytical methods (SR 13511).

Tab. 3. The evolution of diesel concentration in soil

\begin{tabular}{|c|c|c|c|}
\hline $\begin{array}{l}\text { Type } \\
\text { electrode }\end{array}$ & $\begin{array}{c}\text { Initial analysis } \\
\text { [g/kg s.u. }\end{array}$ & $\begin{array}{c}\text { Analysis after } 15 \text { days } \\
{[\mathrm{g} / \mathrm{kg} \text { s.u.] }}\end{array}$ & $\begin{array}{c}\text { Analysis after } 30 \text { days } \\
{[\mathrm{g} / \mathrm{kg} \mathrm{s.u} \text {. }]}\end{array}$ \\
\hline Anode & 106 & 61 & 55 \\
\hline Cathode & 106 & 44 & 37 \\
\hline
\end{tabular}


The total quantity of diesel collected and then extracted from the process of electro-flushing was $38 \%$. The difference corresponding to the maximum remediation percentage is due to the electro-oxidation processes.

As a result, after the application of electro-flushing treatment conducted to a remediation percentages up to $42 \%$ after 15 days, and up to $65 \%$ after 30 days (Fig. 3).

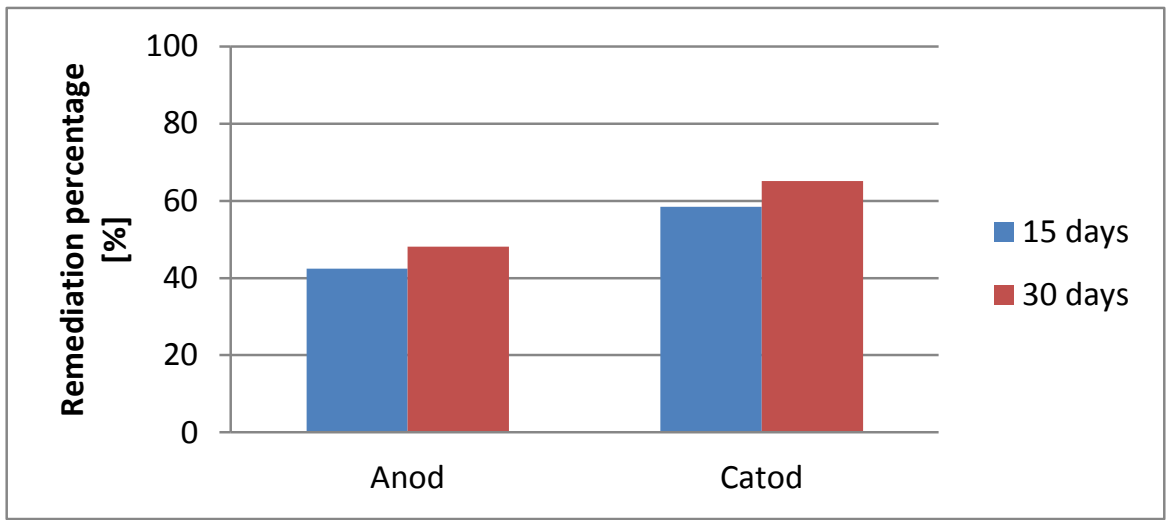

Fig. 3 - The evolution of the remediation process in time

In order to assess the combined method of electro-flushing also from the energy consumption point of view, the specific energy consumption was calculated using the following equation (Reddy and Chinthamreddy, 2003):

$$
E=\frac{1}{V_{S}} \int V l d t
$$

where:

$\mathrm{E}$ is the specific energy consumption $\left[\mathrm{kWh} / \mathrm{m}^{3}\right]$,

$\mathrm{V}_{\mathrm{s}}$ is the treated soil volume $\left[\mathrm{m}^{3}\right]$,

I is the current that was considered constant for al treatment $[\mathrm{A}]$,

$\mathrm{V}$ is the electrical current voltage during the experiment $[\mathrm{V}]$.

Consequently, for a treatment that has been applied for a period of 30 days and with a constant current of density of $1 \mathrm{~mA} / \mathrm{cm}^{2}$, a specific energy consumption of $16 \mathrm{kwh} / \mathrm{m}^{3}$ of treated soil was obtained. 


\section{Conclusions}

By combining the two methods (the electroremediation and soil flushing), it was proved that using the electro-flushing method it can be obtained good removal percentages for diesel polluted soil: an average efficiency of about $46 \%$ for a treatment period of 30 days, comparing with 30\% for flushing and 35-40\% for electroremediation if the remediation methods are separately used. More than that, through this method, the pollutant destruction can be achieved and a recovery up to $30 \%$ from the initial quantity (Beckett et al, 1997) could be done. As results showed, it can be noticed the fact that, the final remediation rate increases with increasing the treatment period. The same tendency was observed also at the tests performed only with electroremediation. Energy consumption associated with electro-flushing method is lowest compared to other remedial methods.

According to data from literature (USEPA, 1993), an increase in diesel mobility in soil can be achieved by using cleaning liquid water in combination with different surfactants, thus realizing higher remediation percentages. This type of approach of the electro-flushing method is the subject for further research.

\section{Acknowledgements}

The authors would like to thank the National Authority for Scientific ResearchRomania; the present work was partially supported under the Sectorial Operational Program "Increase of Economic Competitiveness" POSCCE-A2-O2.1.2.-2009-2, RECOLAND ID519, SMIS-CSNR:119, No.182/18.06.2010 (2010-2013), the Romania National Program PN II - CAPACITIES (Module III) - Bilateral Cooperation Romania - China, SOTREAT, Contract no. 614/01.01.2013 (2013 - 2014) and RomanianTurkish Bilateral Agreement, RISKASSESS, Contract no. 606/01.01.2013 (2013 2014).

The authors also extend thank Ph.D. biochemist senior researcher Anca Rovena Lăcătușu for providing results concerning characteristics of diesel oil contaminated soil.

\section{Bibliography:}

Beckett, G.D., Lundegard, P., Practically impractical - the limits of LNAPL recovery and relationship to risk http://inf.ngwa.org/gwol/pdf/972963338.PDF

Gillian A., Harry D., (2002), Influence of diesel fuel on seed germination, Environmental Pollution, Volume 120, Issue 2, Pages 363-370.

Reddy, K.R., Chinthamreddy, S., (2003), Sequentially enhanced electrokinetic remediation of heavy metals in low buffering clayey soils, Journal of Environmental Engineering 130 (4), 442e455.

United States, Environmental Protection Agency, (1993), Soil washing/Soil flushing, Innovative site remediation technology, Volume 3, EPA 542-B-93-012. 
Wang, X., Yu, X., Bartha, R., (1990), Effect of bioremediation on PAH residues in soil, Environmental Science and Technology 24, 1086-1089.

Yalcin B. Acar, Robert J. Galeb, Akram N. Alshawabkeh, Robert E. Marks, Wheel Puppala, Mark Brickad, Randy Parkere (1995), Electrokinetic remediation: Basics and technology status, Journal of Hazardous Materials 40 117- 137. 